\title{
From tradition to landscape architecture - Planting design concept using perennials and bulbs
}

\author{
Zsolt SZÉKELY-VARGA, Timea HITTER (BURU), \\ Alex-Peter COTOZ, Erzsébet BUTA, Maria CANTOR*
}

\author{
Department of Horticulture and Landscaping, Faculty of Horticulture, \\ University of Agricultural Sciences and Veterinary Medicine, Cluj-Napoca, Romania \\ e-mail: szekelyvarga.zsolt@gmail.com, hittertimea@yahoo.com, \\ alex.p.cotoz@gmail.com, ebuta@yahoo.com \\ *Corresponding author: marcantor@yahoo.com
}

Manuscript received July 22, 2019; revised August 22, 2019; Accepted August 31, 2019

\begin{abstract}
Tradition and Modernity", two aspects the University of Agriculture Sciences and Veterinary Medicine of Cluj-Napoca lives by. The current paper presents a case study analysis of a landscape architecture design, combining tradition with modernity. Through the use of traditional Transylvanian patterns, this concept design is based on the use of different plant species and flowering periods. It measures $500 \mathrm{sq} . \mathrm{m}$ and is situated on the campus of the UASVM. Today, there is an increasing interest for bulbs and Lavandula species in landscaping. This is the reason why Lavandula is popular in the design concept presented below. Designed with the use of Romanian traditional patterns and specific colours, two types of ornamental plants are combined: perennials and bulbous plants. This proposal attempts to provide a way of approaching the Romanian landscape, specific to the region it belongs to.
\end{abstract}

Keywords: Lavandula, landscaping, pattern, ornamental plant

\section{Introduction}

"Tradition and Modernity", two aspects the University of Agriculture Sciences and Veterinary Medicine lives by. Celebrating its $150^{\text {th }}$ anniversary [20], a statement is needed to enhance and spread the message of tradition, pride, and heritage. Designed by using the Romanian traditional patterns and specific colours, the proposal is based on combining two types of plants, perennials and bulbous plants. Traditionally, these well-balanced, geometrical shapes were used either as architectural decorations - rectangles, circles, and triangles - or in a wide range of 
colours - yellow, red, white, black, blue, or green - embroidered into the folk clothing. Design elements, such as line, shape, colour, value, or texture, can enhance and accentuate the aesthetic quality and value of a landscape design.

Tradition represents a set of concepts, customs, and beliefs that historically settle within social or national groups, passed on from generation to generation, defining a specific feature for each social group. The traditional landscape architecture design is a mixture between features used in the systematization of lands. Throughout history, traditional gardening in landscape architecture was present in three main categories of garden types: farms and utilitarian spaces, private gardens where the emphasis fell primarily on the quality of life, and the gardens of the upper classes, noblemen, designed to express their power and status. The characteristics of these landscapes varied according to the geographical region, the cultural influences of the neighbouring peoples, and the already existing traditions [9].

Some general guidelines should be established analysing the most representative historical (traditional) gardens - namely, the geometry of the space, preservation of an easy-to-understand landscape frame, and the accent of the constructed structures. Globally, the art of aesthetics in landscape architecture has influenced the way of thinking and perception about beauty of the people we now consider being influential. In Romania, the approach of beauty and the use of style began only at the end of the $18^{\text {th }}$ century [13]. Until then, the Romanian gardens were composed mainly of medicinal and edible plants [8]. It can be said that Wilhelm Meyer was the first person who brought gardening practice in Romania at a European level [17].

Today, there is an increasing interest for the Lavandula species in the health and beauty industry, academic science but also in landscaping architecture design. These plants are giving a little more beauty to the world, lavender being a beauty for every garden and also a favourite perennial plant for gardeners owing to its colour, fragrance, and versatility.

In landscape architecture design, the Hungarian Pharmacy Society chose lavender to be the medicinal and aromatic plant of the year 2018 [19]. This plant was first mentioned and used as a healing plant by Dioscorides in the period of $\mathrm{c}$. 40-90 AD [11]. The botanical name of the Lavender is Lavandula, which was given by Linnaeus. The genus name comes from the Latin term lavare - washing -, referring to the cosmetic uses of the plant. The Lavandula is part of the order Lamiales, family Lamiaceae, subfamily Nepetoideae, tribe Ocimeae [18]. Lavender is a herbaceous perennial plant which grows best in a climate with a cool winter and a warm, sunny summer [14]. For ornamental purposes, lavender is used for landscape architecture planting design, on curbs and in parks, being an unpretentious plant, which does not require much care. This plant embellishes the garden through the blue-violet flowers, and is also preferred near garden 
alleys or planted near the fences for the specific perfume released by the inflorescence during summer. The aim of the current paper is to present a proposal for a specific landscape design, a Transylvanian traditional pattern concept, to achieve a flowering period around the vegetation period, using current species of bulbous and lavender.

\section{Materials and methods}

The present paper outlines a case study analysis of a landscape architecture proposal, a green space measuring 500 sq. $\mathrm{m}$, situated on the campus of the University of Agriculture Sciences and Veterinary Medicine of Cluj-Napoca. The green space chosen for this landscape architecture design concept is divided into two zones of almost symmetrical shape. More specifically, the site is situated in front of the main entrance for the university rectorate building founded 145 years ago. This green area is a north-facing space with enough sunshine for plants to fully develop throughout the year.

For this purpose, a planting combination between perennials and springflowering bulbs, such as Allium, Crocus, Hyacinthus, Narcissus, or Tulipa, were planted in association with shrubs and species that bloom generously at the beginning of the growing season (spring-summer). Based on the Lavandula layout in the summer time, some bulbous plants, such as Dahlia, Canna, Eremurus, Fritillaria, or Gladiolus, the late bloomers, fill an important colour path in the landscape until the end of the decorative season of a garden. Figures 1 and 2 below provide information on certain parameters of the plants under study, such as height, habitat, flowering period, and ornamental plant characteristics.

Lavandula are small aromatic evergreen shrubs with usually narrow, simple, entire, toothed, or lobed leaves and small tubular inflorescences. The 'Dwarf Blue' variety is a low-growing shrub, native to the Mediterranean region.

This evergreen shrub can grow up to $20-30 \mathrm{~cm}$, and it has deep blue flowers during the summer. The 'Nana Alba' variety is a bushy, compact, evergreen shrub that grows up to $30 \mathrm{~cm}$ with white flowers appearing on tall spikes in the summer that are in contrast with the narrow grey-green leaves. The table below (Table 1) includes certain flowering plants in order to create the traditional landscapearchitecture-patterned floral combinations: 


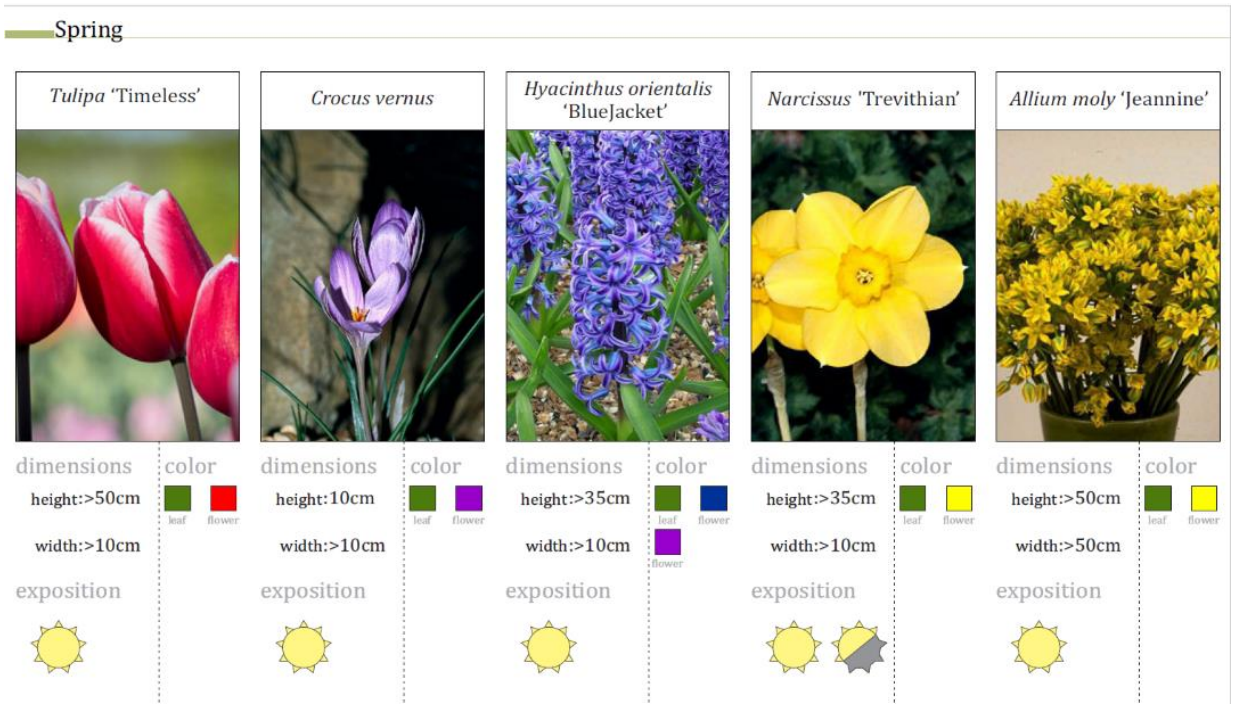

Figure 1. Characteristics of the bulbous species proposed in the spring layout of the landscape (original)

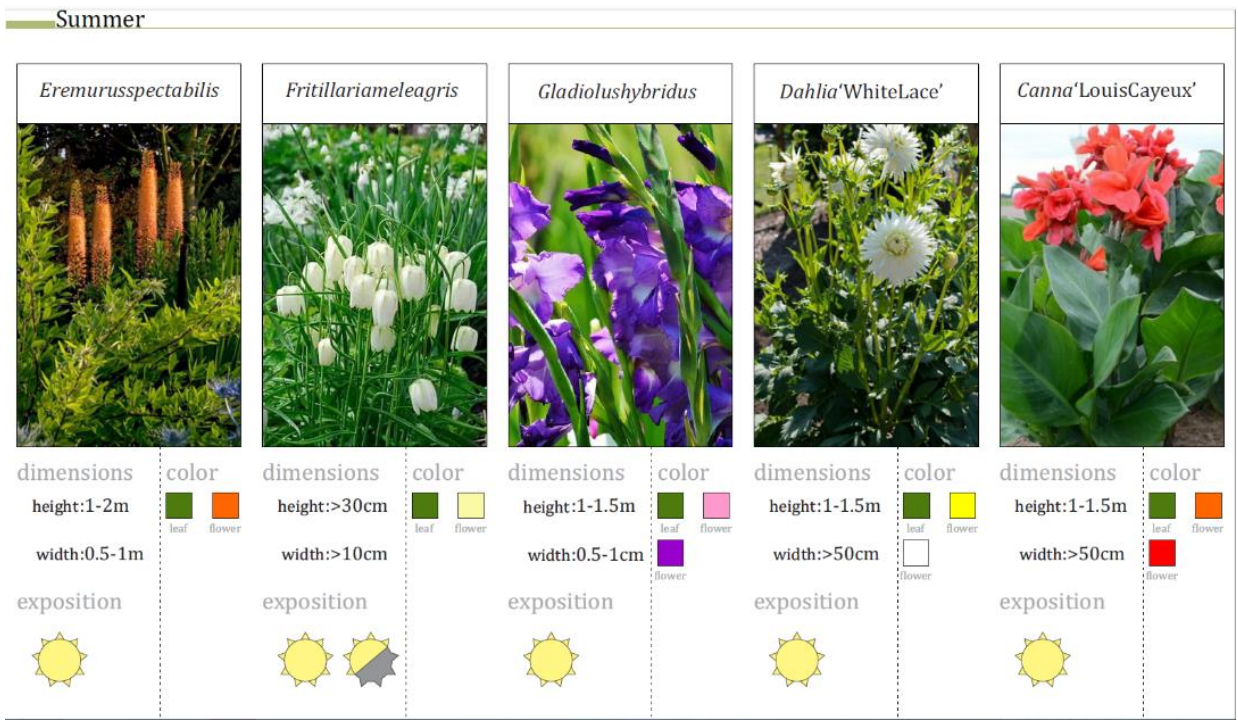

Figure 2. Characteristics of the bulbous species proposed in the summer layout of the landscape (original) 
Table 1. Ornamental plants used in the planting design combinations

\begin{tabular}{|c|c|c|c|}
\hline \multirow{3}{*}{ No. } & \multirow{3}{*}{ SPECIES } & $\begin{array}{l}\text { Planting } \\
\text { material }\end{array}$ & Planting plan \\
\hline & & Quantity & Unit \\
\hline & & (pieces) & (pieces/square meter) \\
\hline \multicolumn{4}{|c|}{ Spring decoration time } \\
\hline 1 & Allium moly 'Jeannine' & 60 & $10 / \mathrm{m}^{2}$ \\
\hline 2 & Crocus vernus & 600 & $600 / \mathrm{m}^{2}$ \\
\hline 3 & Hyacinthus orientalis 'Blue Jacket' & 845 & $65 / \mathrm{m}^{2}$ \\
\hline 4 & Lavandula angustifolia 'Dwarf Blue' & 608 & $8 / \mathrm{m}^{2}$ \\
\hline 5 & Lavandula angustifolia 'Nana Alba' & 232 & $8 / \mathrm{m}^{2}$ \\
\hline 6 & Narcissus sp. 'Trevarthian' & 130 & $65 / \mathrm{m}^{2}$ \\
\hline 7 & Tulipa gesneriana 'Timeless' & 5330 & $65 / \mathrm{m}^{2}$ \\
\hline \multicolumn{4}{|c|}{ Summer decoration time } \\
\hline 1 & $\begin{array}{l}\text { Canna sp. } \\
\text { 'Louis Cayeux' }\end{array}$ & 54 & $10 / \mathrm{m}^{2}$ \\
\hline 2 & Dahlia sp. 'White Lace' & 16 & $10 / \mathrm{m}^{2}$ \\
\hline 3 & Eremurus spectabilis & 820 & $10 / \mathrm{m}^{2}$ \\
\hline 4 & Fritillaria meleagris & 130 & $10 / \mathrm{m}^{2}$ \\
\hline 5 & Gladiolus hybridus & 130 & $10 / \mathrm{m}^{2}$ \\
\hline 6 & Lavandula angustifolia 'Dwarf Blue' & - & $8 / \mathrm{m}^{2}$ \\
\hline 7 & Lavandula angustifolia 'Nana Alba' & - & $8 / \mathrm{m}^{2}$ \\
\hline
\end{tabular}

These ornamental plants were arranged in the form of a heterogeneous mosaic. The design layout of the proposed vegetation combinations was in accordance with the planting plans and shall consider the way in which they are placed. The planting method differs for each plant, depending on the ornamental species used. In accordance with the various plant sizes [1], the following planting plans are used to achieve a proper spread. For example, in the case of Lavandula angustifolia, eight plants are proposed for each square meter (Fig. 3). In the case of the bulbous plants [2] (Fig. 4), Tulipa gesneriana, Crocus vernus, and Hyacinthus orientalis were arranged from 65 to 600 pieces of bulbs in one square meter. In the same manner, 10 pieces of bulbous plants are arranged per square meter [10] for the following species: Allium moly 'Jeannine', Eremurus spectabilis, Fritillaria meleagris, Gladiolus hybridus, Dahlia sp. 'White Lace', and Canna sp. 'Louis Cayeux', highlighted in Fig. 6. 

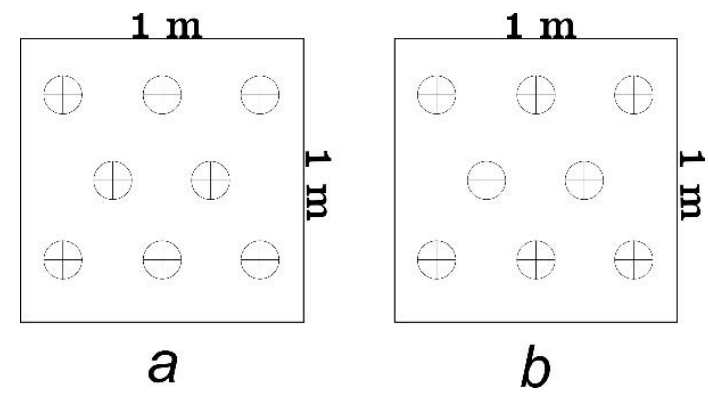

Figure 3. Planting plan for Lavandula angustifolia 'Dwarf Blue' (a) and Lavandula angustifolia 'Nana Alba' (b) (original)

$1 \mathrm{~m}$

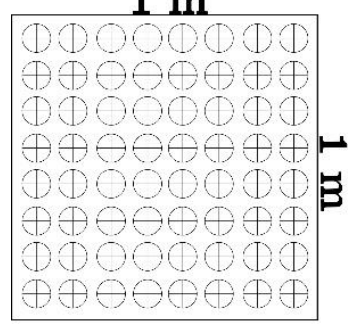

C

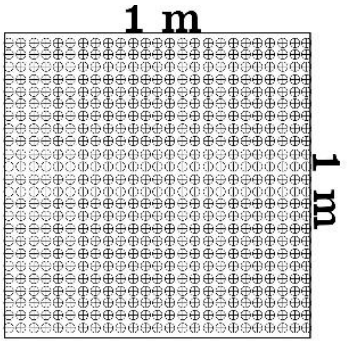

$d$
$1 \mathrm{~m}$

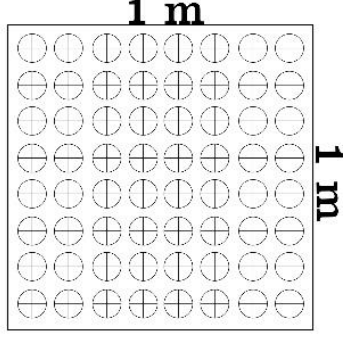

e

Figure 4. Planting plan for Tulipa gesneriana 'Timeless' (c), Crocus vernus (d), and Hyacinthus orientalis 'Blue Jacket' (e) (original)

$1 \mathrm{~m}$

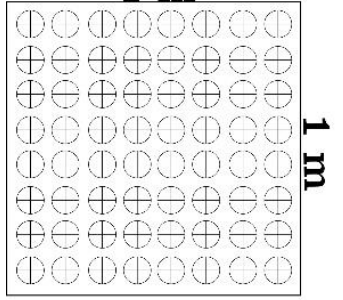

$f$
$1 \mathrm{~m}$

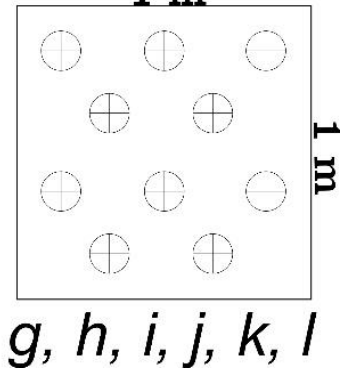

Figure 5. Planting plan for Narcissus sp. 'Trevarthian' (f), Allium moly 'Jeannine' (g), Eremurus spectabilis (h), Fritillaria meleagris (i), Gladiolus hybridus (j), Dahlia sp.

'White Lace' (k), and Canna sp. 'Louis Cayeux' (l) (original)

In creating the concept design, 3D modelling and rendering software were used such as SketchUp 2018, Lumion 6, and CorelDraw 2017. After the topographic plan had been processed and correlated with the existing green area, the $3 \mathrm{D}$ model and the following plan were created as shown in fig-s 6 and 7. 


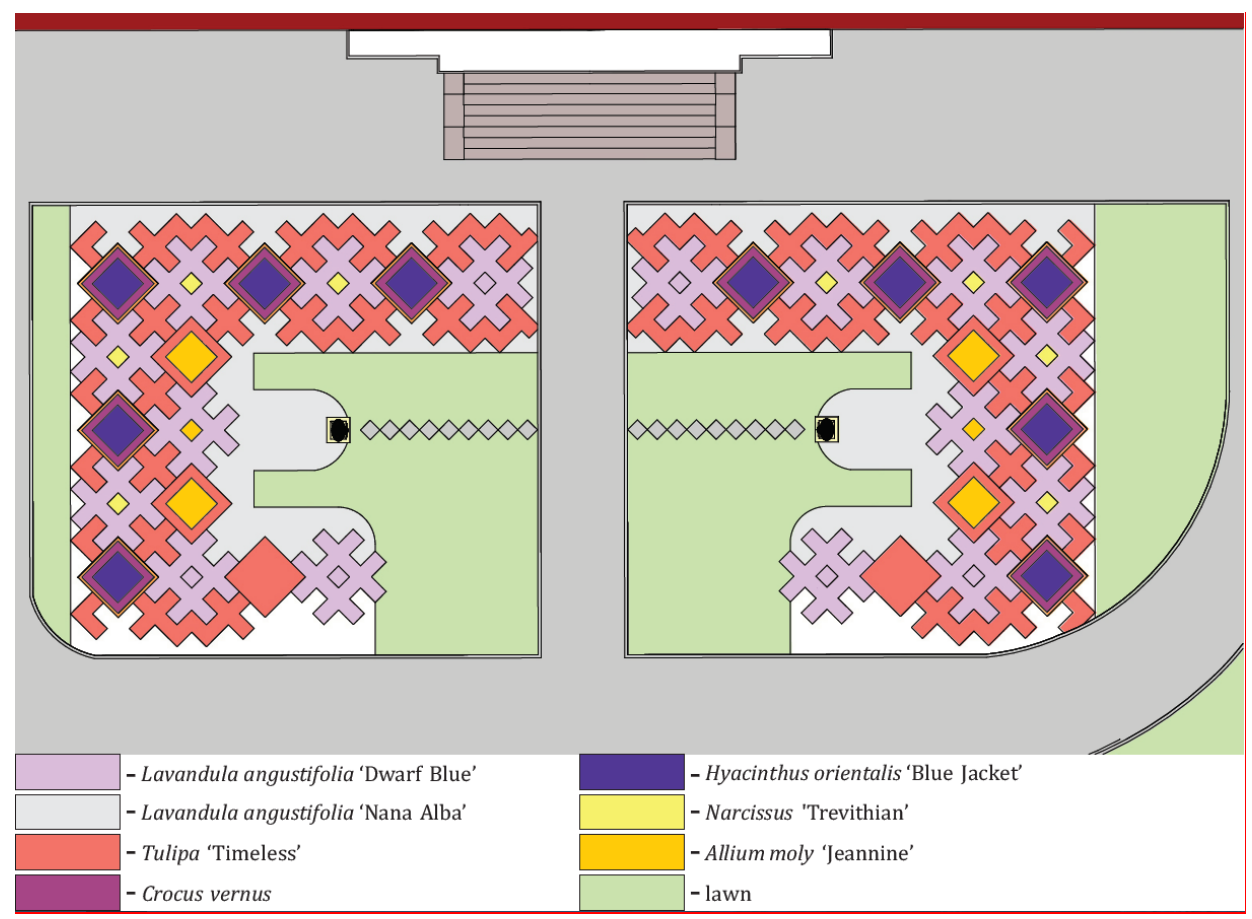

Figure 6. Landscape architecture planting plan for spring decoration (original)

In order to create detailed renders, images were taken on-site and imported into specialized programs to create the virtual world and implicitly the concept design - in this context, the Lumion 6 program, a 3D render software was used to create lifelike representations. Following a sketch as a general guideline, a zoning based on a traditional Transylvanian concept was made, and the floral vegetation placement was chosen according to the decoration period, flowering, colour, texture, size [1,2], and shape. In this case, the decorative transition from spring to summer was eventually achieved. 


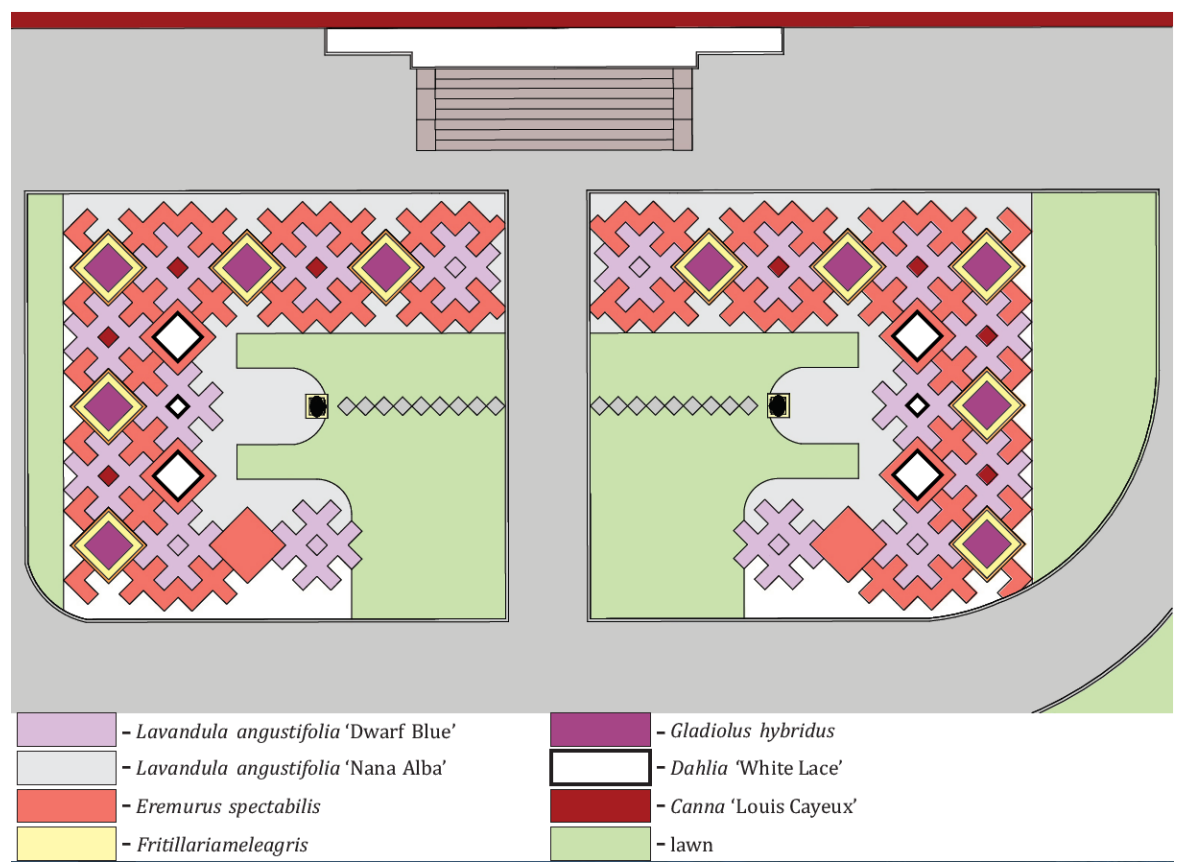

Figure 7. Landscape architecture planting plan for summer decoration (original)

\section{Results and discussions}

Results regarding height and the decoration period of the plants: in order to be able to describe in detail each bulbous and lavender species, observations were made on the important characteristics and properties of ornamental plants. Therefore, proposals will be made for a landscape design concept according to these aesthetic characteristics. In this case, the purpose of our project will be to obtain plant combinations for a great overall effect such as form, colour, contrast, and texture. The height and blooming period of the plants described in Table 2 contribute to the general appearance of the selected species that decorate the proposed landscape [7]. Also, regarding the plant habitat, it can be seen that Crocus vernus is smaller $(10 \mathrm{~cm})$ compared to Eremurus spectabilis, which is the highest bulb species $(200 \mathrm{~cm})$ [5]. Additionally, the Lavandula species have a medium height among the selected ornamental plants.

The flowers are small, blue-violet or white; they are arranged in terminal spiciform inflorescences supported by long, rigid peduncles [6]. It can be seen from Table 2 that the two lavender varieties used for the landscape design have similar habitats. The Lavandula angustifolia 'Dwarf Blue' is $20-30 \mathrm{~cm}$ tall, and its spread is $30-40 \mathrm{~cm}$, while the Lavandula angustifolia 'Nana Alba' has almost the same 
size - height: $30-40 \mathrm{~cm}$, spread: $45 \mathrm{~cm}$. Both lavender varieties' flowering period is almost the same, and, of course, this depends on the weather conditions, flowering typically occurring in June or July and decorating at least for 3-4 weeks.

Table 2. Blooming time and habitat of the studied ornamental plants

\begin{tabular}{|c|c|c|c|c|c|c|c|c|c|c|c|c|c|c|}
\hline \multirow{3}{*}{ No. } & \multirow{3}{*}{ SPECIES } & \multicolumn{12}{|c|}{ Decoration time } & \multirow{3}{*}{$\begin{array}{c}\text { Habitat } \\
\text { Height } \\
(\mathrm{cm})\end{array}$} \\
\hline & & \multicolumn{3}{|c|}{ Spring } & \multicolumn{3}{|c|}{ Summer } & \multicolumn{3}{|c|}{ Autumn } & \multicolumn{3}{|c|}{ Winter } & \\
\hline & & $\mathbf{J}$ & $\mathbf{F}$ & $\mathbf{M}$ & $\mathbf{A}$ & $\mathbf{M}$ & $\mathbf{J}$ & $\mathbf{J}$ & $\mathbf{A}$ & $\mathbf{S}$ & $\mathbf{O}$ & $\mathbf{N}$ & $\mathbf{D}$ & \\
\hline \multicolumn{15}{|c|}{ Bulbs } \\
\hline 1 & Allium moly 'Jeannine' & & & & & & & & & & & & & 50 \\
\hline 2 & $\begin{array}{l}\text { Canna sp. } \\
\text { 'Louis Cayeux' }\end{array}$ & & & & & & & & & & & & & $100-150$ \\
\hline 3 & Crocus vernus & & & & & & & & & & & & & 10 \\
\hline 4 & Dahlia sp. 'White Lace' & & & & & & & & & & & & & $100-150$ \\
\hline 5 & Eremurus spectabilis & & & & & & & & & & & & & $100-200$ \\
\hline 6 & Fritillaria meleagris & & & & & & & & & & & & & 20 \\
\hline 7 & Gladiolus hybridus & & & & & & & & & & & & & $100-150$ \\
\hline 8 & $\begin{array}{l}\text { Hyacinthus orientalis } \\
\text { 'Blue Jacket' }\end{array}$ & & & & & & & & & & & & & $15-25$ \\
\hline 9 & $\begin{array}{l}\text { Narcissus sp. } \\
\text { 'Trevarthian' }\end{array}$ & & & & & & & & & & & & & 35 \\
\hline 10 & $\begin{array}{l}\text { Tulipa gesneriana } \\
\text { 'Timeless' }\end{array}$ & & & & & & & & & & & & & 40 \\
\hline \multicolumn{15}{|c|}{ Perennials } \\
\hline 11 & $\begin{array}{l}\text { Lavandula angustifolia } \\
\text { 'Dwarf Blue' }\end{array}$ & & & & & & & & & & & & & $20-30$ \\
\hline 12 & $\begin{array}{l}\text { Lavandula angustifolia } \\
\text { 'Nana Alba' }\end{array}$ & & & & & & & $\mathbf{x}$ & $\mathbf{x}$ & $\mathbf{x}$ & & & & $20-30$ \\
\hline
\end{tabular}

Table 2 presents the selected bulb and lavender species' flowering phenology $[5,7,12,18]$ because, designing with ornamental plants, a landscape architecture project must be in accordance with the decoration period, shape, colour, and blooming time. It can be seen that the predominant colours are the complementary shades, such as yellow or purple, combined with white flowers.

Analysing the planting period of the bulbs, it is important to achieve the proposed planting design by respecting the specific time frame as shown in Table 3. For example, bulbs such as Allium moly, Crocus vernus, Fritillaria meleagris, Hyacinthus orientalis, Narcissus sp., and Tulipa gesneriana have to be planted in the autumn in order to obtain the expected spring blooming layout [5].

Lavender (Table 3) can be planted in two time periods of the year, in the spring-summer and autumn. In the spring-summer period, it is recommended to plant the lavender from March to May, and in the autumn period it is best to plant it in September or October, depending a lot on the climate conditions for the specific region. The planting distance between plants depends on the cultivated 
lavender varieties. In landscape planting design, there have been no reliable data until now; the lavender plants surely need to be planted at least $50 \mathrm{~cm}$ apart from each other to have a well-developed and -formed lavender shrub.

Table 3. Planting period in landscape design layout

\begin{tabular}{|c|c|c|c|c|c|c|c|c|c|c|c|c|c|}
\hline \multirow{3}{*}{ No. } & \multirow{3}{*}{ SPECIES } & \multicolumn{12}{|c|}{ Planting period } \\
\hline & & \multicolumn{3}{|c|}{ Spring } & \multicolumn{3}{|c|}{ Summer } & \multicolumn{3}{|c|}{ Autumn } & \multicolumn{3}{|c|}{ Winter } \\
\hline & & $\mathbf{J}$ & $\mathbf{F}$ & $\mathbf{M}$ & $\mathbf{A}$ & $\mathbf{M}$ & $\mathbf{J}$ & $\mathbf{J}$ & $\mathbf{A}$ & $\mathbf{S}$ & $\mathbf{O}$ & $\mathbf{N}$ & $\mathbf{D}$ \\
\hline \multicolumn{14}{|c|}{ Bulbs } \\
\hline 1 & Allium moly 'Jeannine' & & & & & & & & & & & & \\
\hline 2 & Canna sp. 'Louis Cayeux' & & & & & & & & & & & & \\
\hline 3 & Crocus vernus & & & & & & & & & & & & \\
\hline 4 & Dahlia sp. 'White Lace' & & & & & & & & & & & & \\
\hline 5 & Eremurus spectabilis & & & & & & & & & & & & \\
\hline 6 & Fritillaria meleagris & & & & & & & & & & & & \\
\hline 7 & Gladiolus hybridus & & & & & & & & & & & & \\
\hline 8 & $\begin{array}{l}\text { Hyacinthus orientalis 'Blue } \\
\text { Jacket' }\end{array}$ & & & & & & & & & & & & \\
\hline 9 & Narcissus sp. 'Trevarthian' & & & & & & & & & & & & \\
\hline 10 & $\begin{array}{l}\text { Tulipa gesneriana } \\
\text { 'Timeless' }\end{array}$ & & & & & & & & & & & & \\
\hline \multicolumn{14}{|c|}{ Perennials } \\
\hline 11 & $\begin{array}{l}\text { Lavandula angustifolia } \\
\text { 'Dwarf Blue' }\end{array}$ & & & & & & & & & & & & \\
\hline 12 & $\begin{array}{l}\text { Lavandula angustifolia } \\
\text { 'Nana Alba' }\end{array}$ & & & & & & & & & & & & \\
\hline
\end{tabular}

The design proposal aims were to create a green space consisting of spring and summer using ornamental plants to create a floral mosaic carpet with a design specific to the traditional Romanian concept. The traditional pattern used in this case comes from the Transylvanian region of Romania. It is mainly composed of straight lines forming squares and rectangles perpendicular on each other.

To achieve balance, two equal parts were created thus, resulting in the continuous symmetry of the studied area. The repeated placement of the ornamental plants, both in the foreground and in the background, in right-angled shapes, links the space with the rest of the composition, creating unity and harmony. As unifying elements of the design concept, light-coloured gravel and lawn were used to further enhance the contrast with the surroundings.

Two scenarios are presented in the following figures for the spring and summer design concept arrangements. The first one (Fig. 8) was composed mainly by bulbous floral species and as a perennial unifying element such as lavender. The second arrangement presented in Fig. 9 was composed of perennial floral species, their decoration period starting in early summer. 


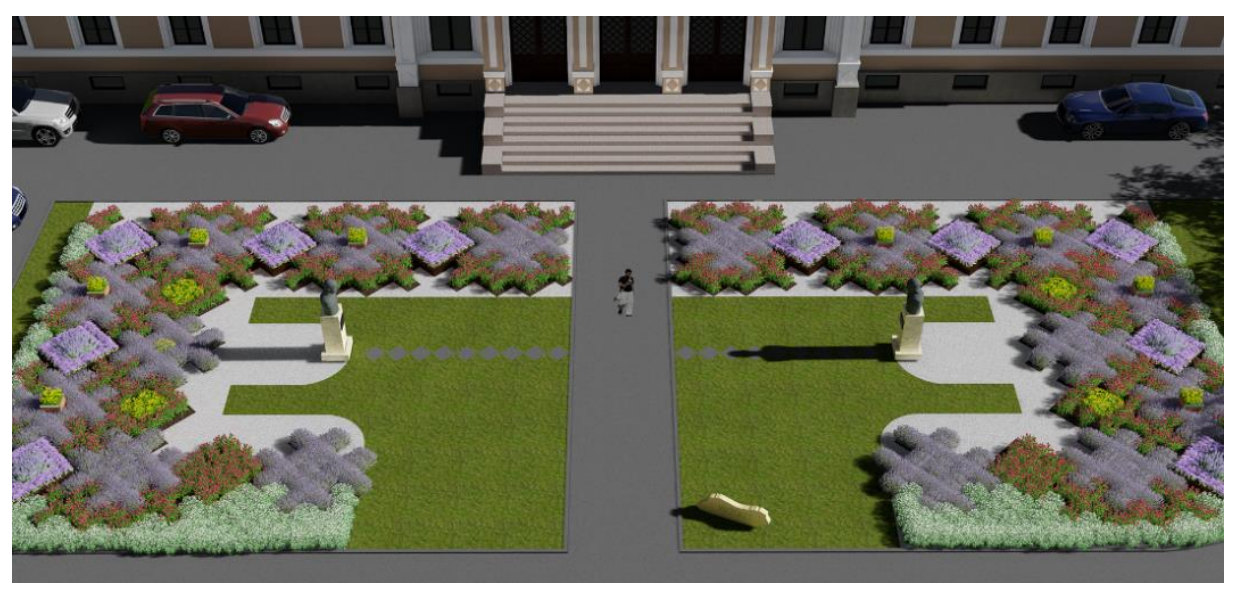

Figure 8. Spring decoration representation of the proposed landscape design (original)

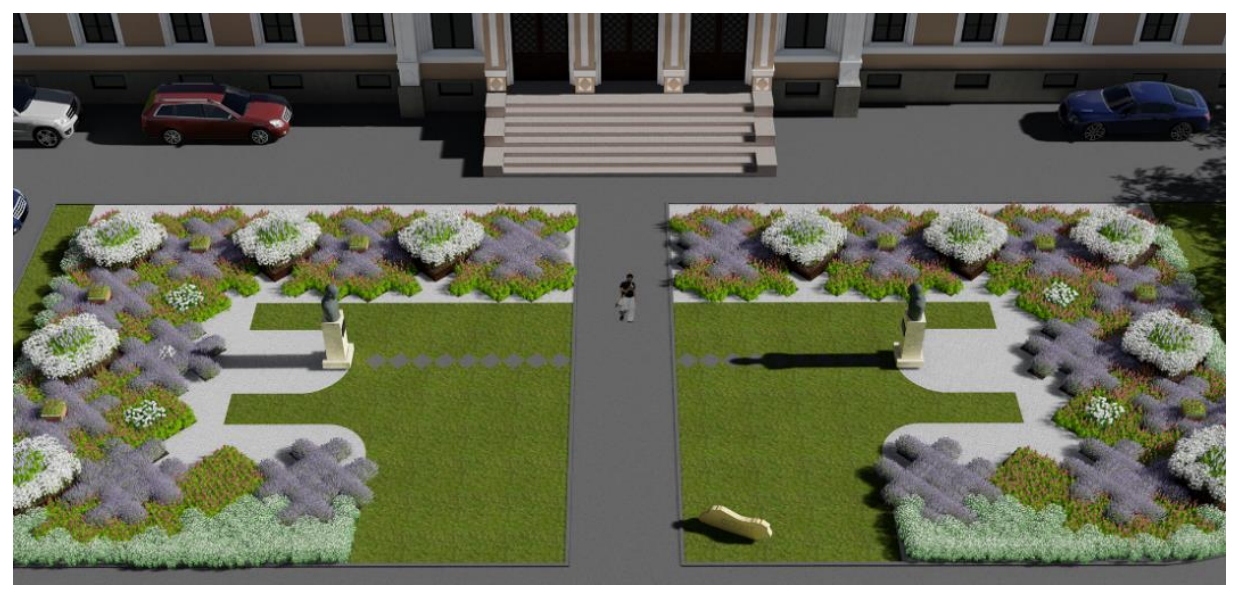

Figure 9. Summer decoration representation of the proposed landscape design (original)

Due to the shape of the existing green area, the zone in divided into two parts. The north-eastern zone is almost the same as the north-western one but smaller is size. In the next part, following the planting plan and using a 3D rendering software, we can observe the ornamental plant arrangement during spring and summer time (Fig. 10). In the spring layout, bulbous species, such as Allium moly, Crocus vernus, and Tulipa gesneriana, were proposed in the combination of the Lavandula angustifolia 'Dwarf Blue' and 'Nana Alba' species in summer. 

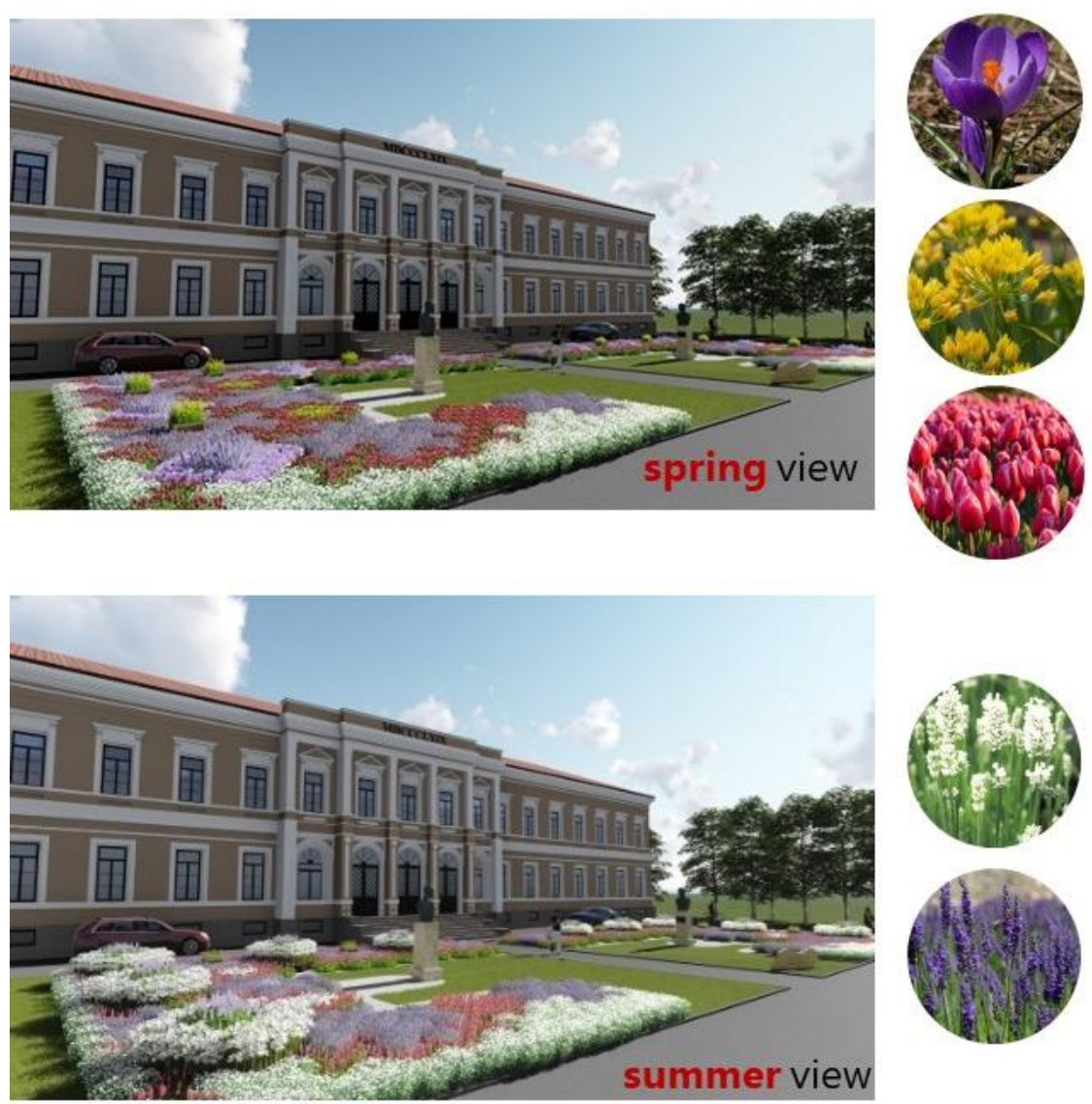

Figure 10. Spring and summer decoration in the north-eastern view (original)

The north-western area is bigger in size than the previously presented one. The planting plan layout of bulbous species accomplish the traditional pattern by using Narcissus sp. and Hyacinthus orientalis for the spring time decoration and Canna sp. 'Louis Cayeux', Dahlia sp. 'White Lace', and Fritillaria meleagris in the summer design (Fig. 11). 

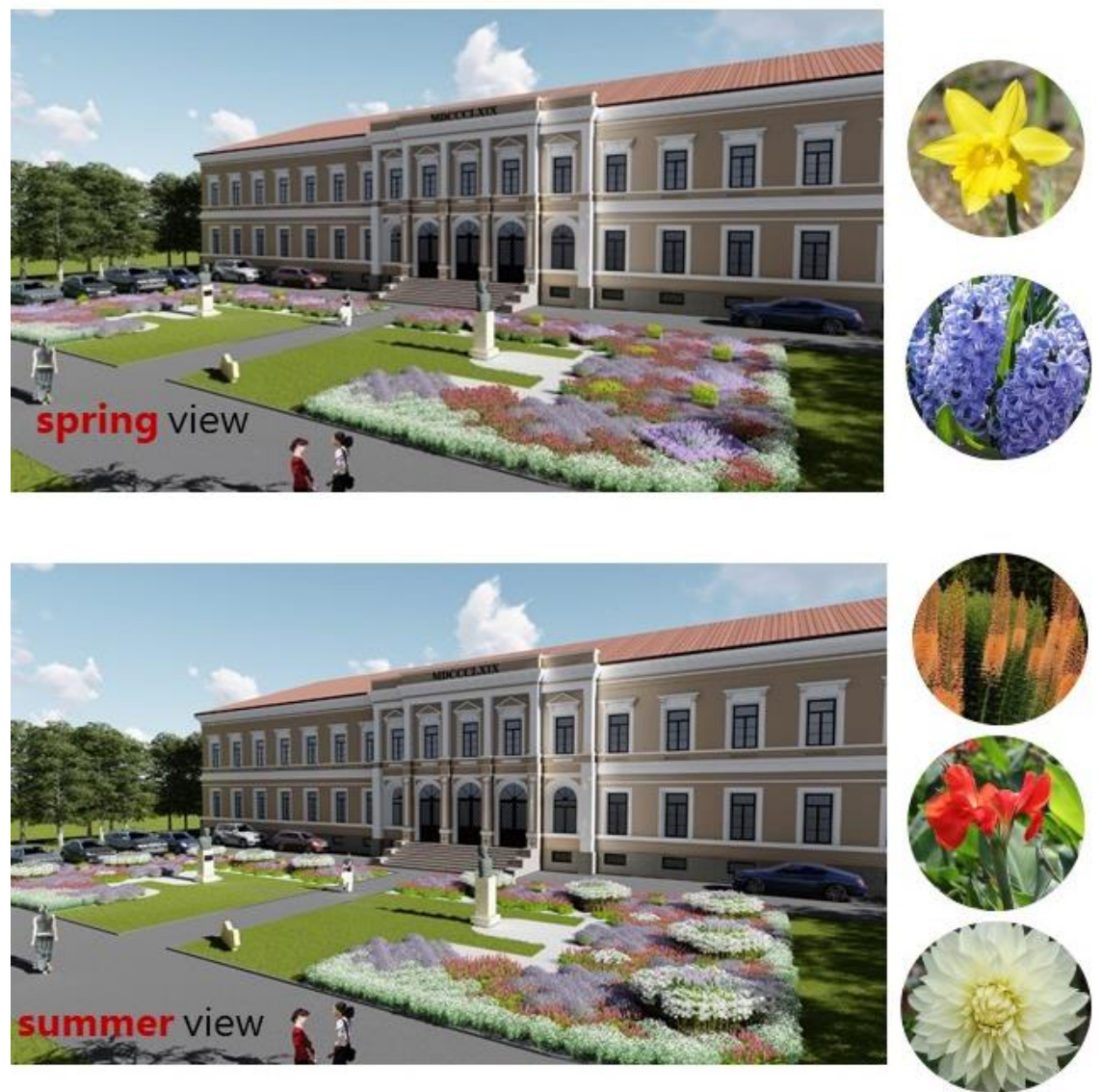

Figure 11. Spring and summer decoration in the north-western view (original)

The proposed vegetation layout gives passers-by an effect of movement and a certain amount of dynamism in the shape of a floral mosaic composition. This colourful and rigorous use of plants gives a clear picture of the whole design concept and a degree of unity in the landscape at the same time.

\section{Conclusions}

In landscape design, the human mind will always find well-balanced, regular shapes such as circles, squares, or rectangles more appealing than other, asymmetrical shapes. Introducing new bulbous varieties in local planting design can increase variety in terms of colour, shape, blooming, and decoration period. Also, perennials, such as lavender, in a planting design composition can be 
valuable ornamental plants with a permanent decorative element during de vegetation period. Traditional Transylvanian patterns are one of the most representative elements in our local history, and by using landscape architecture one can place emphasis on local identity and heritage.

Whenever someone hears the word lavender, it certainly flashes in their mind an image of a big field full of blue/violet flowers and that very specific Lavandula fragrance. So, thanks to these features, lavender plants are required more often by garden owners, or they are used by the landscapers in Romania for landscaping designs.

\section{References}

[1] Addai, I., Scott, P. (2011), Influence of bulb sizes at planting on growth and development of the common hyacinth and the lily. Agriculture and Biology Journal of North America 2, 298-314.

[2] Ahmad, I., Ahmad, T. Asif, M., Saleem, M., Akram, A. (2009), Effect of bulb size on growth, flowering and bulbils production of tuberose. American-Eurasian J. Agric. \& Environ. Sci. 25(3), 391-397.

[3] Bernáth, J. (2000), Gyógy- és aromanövények. Budapest: Mezőgazda Kiadó. 384-389.

[4] Cantor, M. (2016), Floricultură specială - Manual didactic. Cluj-Napoca: AcademicPres.

[5] Cantor, M., Dumintras, A., Zaharia, D. (2007), Plante bulboase utilizate în amenajări peisagistice. Editura Todesco.

[6] Draghia, L., Chelariu, E. L. (2011), Floricultură. Brad, Iași: Ion Ionescu.

[7] Dumitraş, A., Singureanu, V., Sabo, G. (2008), Principii generale de proiectare şi amenajare a spatiilor verzi. AcademicPres.

[8] Glăman, G., Vlăduț. M. (2003), Floricultura și arta grădinăritului la Români. Bucharest: Ceres.

[9] Iliescu, A. F. (2003), Arhitectura peisageră. Bucharest: Ceres.

[10] Kumar, K., Singh, C. N., Beniwal, V. S., Pinder, R. (2016), Effect of spacing on growth, flowering and corn production of gladiolus (Gladiolus sp.) cv. American Beauty. International Journal of Environment, Agriculture and Biotechnology (IJEAB) 1(3), 550554. ISSN: 2456-1878.

[11] Lis-Balchin, M. (2004), Lavender. Handbook of herbs and spices. Vol. 2. Peter KV, Woodhead Publishing Ltd \& CRC Press.

[12] Lord, T., Lawson, A. (2012), Encyclopedia of planting combinations: Over 4000 color and planting schemes. Firefly Books.

[13] Marcus., R. (1958), Parcuri și grădini din România. Bucharest: Ed. Tehnică.

[14] Mason, J. (2014), Growing and knowing lavender. ACS Distance Education.

[15] McCoy, J. A. (2001), Lavender: History, taxonomy, and production. North Carolina State University.

[16] Roman, G. V., Morar, G., Robu, T., Ștefan, M., Tabără, V., Axinte, M., Borcean, I., Cernea, S. (2012), Fitotenie. Vol. II. Plante tehnice, medicinale și aromatice. Bucharest: Ed. Universitară. 375-377.

[17] Toma, D. (2001), Despre grădini și modurile lor de folosire. Iași: Polirom.

[18] Toma, F. (2009), Floricultură și artă florală. Vol. IV. Specii utilizate pentru decorul parcurilor şi grădinilor. Bucharest: Invel Multimedia.

[19] *** http://www.mgyt.hu/hu/mgyt-hirek/387-ev-gyogynovenye-2018.

[20] *** https://www.usamvcluj.ro/. 